University of Wyoming College of Law

Law Archive of Wyoming Scholarship

$1-31-2010$

\title{
Problem of Critique: Triangulating Habermas, Derrida, and Gadamer within Metamodernism
}

Stephen Matthew Feldman

University of Wyoming College of Law, sfeldman@uwyo.edu

Follow this and additional works at: https://scholarship.law.uwyo.edu/faculty_articles

\section{Recommended Citation}

Feldman, Stephen Matthew, "Problem of Critique: Triangulating Habermas, Derrida, and Gadamer within Metamodernism" (2010). Faculty Articles. 98.

https://scholarship.law.uwyo.edu/faculty_articles/98

This Article is brought to you for free and open access by the UW College of Law Faculty Scholarship at Law Archive of Wyoming Scholarship. It has been accepted for inclusion in Faculty Articles by an authorized administrator of Law Archive of Wyoming Scholarship. 
The Problem of Critique: Triangulating Habermas, Derrida, and Gadamer Within Metamodernism $^{1}$

Stephen M. Feldman ${ }^{2}$

${ }^{1}$ C 2003 Stephen M. Feldman.

${ }^{2}$ Jerry W. Housel/Carl P. Arnold Distinguished Professor of Law and Adjunct Professor of Political Science, University of Wyoming. I thank Dennis Patterson for his comments on an earlier draft. 


\section{The Problem of Critique: Triangulating Habermas, Derrida, and Gadamer Within Metamodernism}

Few commentators have explicitly discussed the relationships among Hans-Georg Gadamer's philosophical hermeneutics, Jürgen Habermas's communication theory, and Jacques Derrida's deconstruction, taken all together. Many commentators have discussed at least two of them, sometimes trying to synthesize or harmonize them (Risser, 1997). Paul Ricoeur argued that Gadamer and Habermas share a "zone of intersection" (Ricoeur, 1981, 79). Thomas McCarthy strongly criticized Derrida yet maintained that "a number of deconstructive motifs and techniques, stripped of their totalizing pretensions, could be integrated into a [Habermasian] pragmatic approach to communication" (McCarthy, 1991, 6). Many other commentators, though, have concluded that the respective philosophies are inconsistent. Ernst Behler, for example, has emphasized "the incommensurability and incompatibility" of philosophical hermeneutics and deconstruction (Behler, 1991, 144). Habermas himself has had a celebrated disagreement with Gadamer and has sharply criticized Derrida. Derrida responded by calling Habermas precipitous and dogmatic (Derrida, 1988, 157 n.9). Meanwhile, Gadamer and Derrida have had two well-known but largely fruitless meetings (Madison, 1989, 192). Even Richard J. Bernstein, who has interpreted all three philosophers sympathetically, concluded that Habermas and Derrida, for instance, can supplement each other but ultimately cannot be reconciled (Bernstein, 1991, 201).

My purpose is twofold. First, I analyze how Habermas, Gadamer, and Derrida all fit together within one philosophical paradigm, which I call metamodernism. A paradigm, as I use the term in this essay, is a world-view, a set of presupposed beliefs that pervasively shapes one's perceptions of and orientation toward the world. Habermas, Gadamer, and Derrida, to be sure, disagree with each other in significant ways, but the disagreements are those that might arise within a shared paradigm. These three philosophers, in other words, share certain fundamental 
presuppositions about our being-in-the-world even though, to some extent, they have different aims and ask different questions.

The importance of this part of the essay arises from the all-too-common precipitate denunciations of these philosophers, especially Derrida, for being incomprehensible, nihilistic, postmodern, and so forth. For instance, Brian Leiter excoriates "postmodernists and deconstructionists" for their "sophomoric jargon" (Leiter, fall 1998, 14). Ronald Dworkin grossly groups all postmodernists together and accuses them of presenting their own views as mere "subjective displays in which we need take nothing but a biographical interest" (Dworkin, 1996, 88). John Searle likewise groups all postmodernists together and denounces them for being motivated by a "will to power" (Searle, 1998, 19). I argue that such hasty dismissals, when directed at Gadamer, Habermas, or Derrida, are based on serious mischaracterizations of their most basic presuppositions - presuppositions that they share within the metamodernist paradigm.

Second, I analyze the relationships among Habermas, Gadamer, and Derrida within metamodernism. My specific thesis is that a political conundrum provides the key clue for understanding the relations among the three and for elaborating the contours of the metamodernist paradigm. Philosophies often are explicitly political or have political implications, when understood in accordance with the traditional dichotomy between liberal (or, leaning to the left) and conservative (or, leaning to the right). In ordinary terms, political liberals tend to question the status quo, often expressing concern about the plight of the oppressed; to countenance governmental intervention in the economic marketplace; and to favor individual independence in opposition to the governmental imposition of moral values. Political conservatives tend to celebrate the status quo; to emphasize individual independence and merit, especially in the economic marketplace; and to favor the preservation of traditional religious and moral values, even if requiring governmental assistance (Shiffrin, 1999, 123-24). Given this political dichotomy, we might expect philosophies to obey a law of political transitivity: if the philosophy of thinker A is more conservative than that of thinker B, and the philosophy of B is 
more conservative than that of $\mathrm{C}$, then the philosophy of $\mathrm{A}$ would be more conservative than that of C.

This law of transitivity, however, does not hold true with the political implications of Gadamer's, Habermas's, and Derrida's philosophies. Rather, at times, Gadamer seems to the right of both Habermas and Derrida, but then, at different times, he stands between them, and then again, at other times, he seems to be to the left of both. The same is true if we try to pinpoint the positions of either Habermas or Derrida. To be clear, I am concerned with the political implications of the three philosophies rather than the self-proclaimed political stances of the individual philosophers. Thus, Habermas might view himself as being left-liberal (Lessnoff, 1999, 269), yet my analysis identifies the implications of his communication theory as variegated, sometimes to the left and sometimes to the right. This conundrum - this intransitivity of political implications for the three philosophies-provides the crucial component for relating hermeneutics, communication theory, and deconstruction. The three philosophersor more precisely, the three philosophies - should be triangulated: they should be understood in relation to each other as if they were the three corners of a triangle, situated within the paradigm of metamodernism. As illustrated in the following diagram, Gadamer (and philosophical hermeneutics) is at one corner, Habermas (and communication theory) is at another, and Derrida (and deconstruction) is at the third.

The diagram is not meant to suggest that Gadamer must be at the top corner, with Habermas at the left, and Derrida at the right. Rather, the triangle could spin on its center point so that any philosopher could be at any corner. In fact, that possible rotation underscores the crucial political problematic. The philosophies of the three thinkers do not stand in fixed political positions vis-à-vis the other two; rather, they rotate about each other within the shared metamodernist paradigm. In fact, the paradoxical political relations among philosophical hermeneutics, communication theory, and deconstruction suggest that the traditional (modernist) 
political categories of liberalism and conservatism do not adequately reflect the critical positions within metamodernism. Gadamer, Habermas, and Derrida are far more concerned with explaining the possibility and techniques of interpretive and social critique, while remaining true to the metamodernist paradigm, rather than fitting themselves into the traditional liberal or conservative political camps.

Part I of this essay introduces the paradigm of metamodernism and explains how Gadamer, Habermas, and Derrida all fit within it. Part II analyzes the relations among the three philosophers, focusing especially on the problematic political ramifications of their philosophies. Part III analyzes how the problem of interpretive and social critique animates the disputes among Gadamer, Habermas, and Derrida as well as contributes to the political intransitivity of their respective philosophies.

\section{Metamodernism}

Metamodernism is best understood in comparison to modernism. Modernism, often associated with Enlightenment thought, entails a commitment to a subject-object metaphysics that traces back to Descartes: the self or subject stands separate from an objective world. In epistemology, then, modernists are foundationalists: "knowledge can only be justified to the extent it rests on indubitable foundations" (Patterson, 1992, 263). Knowledge, that is, requires the subject to access a firm foundation or Archimedean point, typically the objective world. Even the epistemological skeptic is a foundationalist because the skeptic accepts this conception of knowledge, though denying or doubting that we can achieve it (Patterson, 1992, 265-66). Modernists, moreover, commonly subscribe to a correspondence theory of truth and a referential theory of language (Murphy, 1997, 2, 8, 18). Correspondence theory arises from an intuition that truth must be grounded on a relation between our beliefs and the way the world is: "A proposition is true just in case it corresponds to facts or the world" (Schmitt, 1995, 145). This conception of truth is intertwined with a referential notion of language, according to which "language consists of propositions which picture the world" (Kenny, 1998, 331). For instance, as explained in early Wittgensteinian philosophy, "[p]ropositions are the perceptible expressions 
of thoughts, and thoughts are logical pictures of facts" (Kenny, 1998, 331). Today, Searle is an exemplary modernist, maintaining that "there is a reality that exists totally independently of us, an observer-independent way that things are, and our statements about that reality are true or false depending on whether they accurately represent how things are" (Searle, 1998, 134). Thus, if the modernist subject cannot bridge the gap to and connect with the objective world, then the subject is left floating untethered through an abyss of relativism and nihilism.

To understand or to know the meaning of a text, according to the modernist view, the self or subject needs to implement a method or technique that allows access to an objective textual meaning and that often entails overcoming or neutralizing the reader's prejudices. This modernist approach to understanding is familiar in jurisprudence. Many constitutional theorists assert that to understand the objective meaning of a constitutional provision, a judge supposedly needs to ascertain the framers' intentions. "The interpretation of the Constitution according to the original understanding," Robert Bork insists, "is the only method that can preserve the Constitution" (Bork, 1990, 159). If a judge does not invoke such a method to divulge the objective meaning in this manner, then the judge inevitably becomes an unconstrained rogue, and constitutional interpretation becomes a political free-for-all where anything goes. In the words of Sanford Levinson, echoing Richard Rorty, the constitutional interpreter (or judge), in this event, "simply beats the text into a shape which will serve his own purpose"” (Levinson, 1982, 385; Rorty, 1982, 151).

Metamodernism not only rejects modernist subject-object metaphysics, epistemological foundationalism, and referential theories of language, but further dismisses these concerns as insignificant in comparison to other more pressing issues. Habermas, for instance, unequivocally declares himself to be "postmetaphysical" (Habermas, 1996, 443). Instead of the typical modernist concerns, then, Habermas and other metamodernists tend to emphasize the operation and orientation of power, particularly in language. Gadamer writes that " $[\mathrm{t}]$ he speaking of a language is a totality, a structure within which we have our place - a place which we have not chosen" (Gadamer, 1998, 29). Working from within this focus on linguistic power, 
philosophical hermeneutics, communication theory, and deconstruction all share a central aim: to identify the conditions of human understanding from a metamodernist vantage (that is, without accepting subject-object metaphysics).

I use the term metamodernism, rather than postmodernism, partly because postmodernism (or postmodernity) carries so much baggage-especially burdensome or negative baggage. Yet, I am not merely substituting the word metamodernism for postmodernism. I am instead making a finer distinction. In particular, I distinguish metamodernism not only from modernism but also from antimodernism. As between metamodernism and antimodernism, antimodernism is the more extreme; it encompasses a belief in radical relativism. Appeals to reason are no more than rhetorical moves that assert the dominance of one's own cultural standpoint. There is no way to adjudicate among competing claims to truth and knowledge. When it comes to textual interpretation, anything goes. Antimodernism is encountered most often, perhaps, in the deconstructive writings of some literary theorists (Bloom, 1979, 4). Without doubt, it encompasses the manifestations of postmodernism that most often provoke the ire of so many (modernist) commentators.

Partly for that reason, the distinction between antimodernism and metamodernism is significant. ${ }^{1}$ Metamodernism is more moderate. Like modernists, metamodernists might explain, for example, how we use reason, have knowledge, and discuss truth. Unlike modernists, though, metamodernists explain these concepts without invoking the firm epistemological foundations of subject-object metaphysics. Metamodernists tend to emphasize our situatedness: we are always situated in a communal or cultural context. As such, we are always, in a sense, limited. A metamodernist, therefore, would never suggest that anything goes, because from within our limits - from within our situatedness or contextuality—is how we understand anything and everything.

The two common alternative interpretations of Thomas Kuhn's philosophy of science might help clarify the distinction between metamodernism and antimodernism. Kuhn argued that, according to a traditional view of science, scientific practice is objective, mechanistic, and 
progresses in a linear fashion: scientists supposedly progress in their knowledge of nature as they develop theories based on the neutral observation of brute objective data. Kuhn repudiated this traditional view. He argued that scientists instead understand or interpret the world in accordance with or through a paradigm. The scientific community's paradigm shapes the questions that scientists find interesting and appropriate for research, and even more important, the paradigm shapes the scientists' perceptions of data. Kuhn therefore suggested that science might progress by becoming more complex and specialized as it moves from one paradigm to another, but contrary to the traditional view, science does not necessarily move closer and closer to some objective truth (Kuhn, 1970).

Kuhn's argument has been subject to two dominant but strongly opposed readings. According to one interpretation of Kuhn — call it the antimodern interpretation-his repudiation of the traditional view of science and his focus on scientific paradigms renders true science impossible. Science becomes, at most, a culturally relativistic practice, and at worst, a practice in which anything goes. According to a second (and I believe correct) interpretation, however, Kuhn is a metamodernist. He explains exactly how science is possible, even though we cannot meaningfully access any type of brute data. When a scientist participates in a communal paradigm, she is, in a sense, equipped with tools that enable her to practice science. She knows what questions are interesting, how to search for data, how to present findings, and so forth.

Gadamer, Habermas, and Derrida are all metamodernists. They reject the subject-object metaphysics of modernism and its correlative methods for textual understanding and interpretation as they seek to identify the conditions of human understanding. Gadamer might be the best exemplar of metamodernism. ${ }^{2}$ His philosophical hermeneutics is, as he puts it, ontological. Our being-in-the-world is hermeneutic: we are always and already interpreting. The subject or self never stands separately and independently from the objective world, and hence, "our perception is never a simple reflection of what is presented to the senses" (Gadamer, 1989d, 90). 
Gadamer emphasizes that we all are situated or live within the cultural tradition (or traditions) of a community. The communal tradition inculcates each individual with prejudices that open us to the possibility of understanding textual meaning. Thus, whereas the modernist insists that prejudices must be overcome or banished so that we can perspicaciously understand a text, Gadamer argues that prejudices are a necessary prerequisite to textual understanding (Gadamer, 1980, 133). Prejudices enable or empower us. As soon as we turn to a text, our prejudices imbue us with a fore-understanding — a first understanding of the text that initiates and orients the remainder of the interpretive process. As one penetrates deeper into the text, our foreunderstanding can give way to more refined interpretations of the text, and indeed, our prejudices can be transformed during this process. Yet, without our prejudices, derived from communal tradition (or "effective history"), interpretation cannot even begin (Gadamer, 1989d, 301).

Significantly, though, prejudices not only enable but also constrain understanding. We never are free and independent subjects floating untethered through an abyss: "[s]uch a freedom, such a standing at a distance from the examined object simply does not exist" (Gadamer, 1998, 28). Rather, our prejudices limit what we can understand and perceive. Our prejudices, in effect, constitute a horizon: "the range of vision that includes everything that can be seen from a particular vantage point” (Gadamer, 1989d, 302). Quite simply, we cannot see beyond our horizon, though our horizon constantly shifts and moves. The Gadamerian maxim that our being-in-the-world is interpretive means, then, that all of our understanding, perceptions, and experiences are simultaneously enabled and constrained by our prejudices, which are derived from communal traditions. Even pre-reflective textual understanding - understanding of a text that seems immediate and plain — arises only because we are already and always situated within our horizons of prejudices and traditions (Gadamer, 1980, 139).

Gadamer analogizes textual understanding to a conversation or dialogue between the interpreter and the text. As soon as the interpreter turns to a text, she presumes that it has something meaningful to say, that it contains some "unity of meaning" that is complete and intelligible (Gadamer, 1989d, 294). To be sure, the interpreter begins with a fore-understanding 
of the text, but by questioning the text, listening to its answers, asking new questions, listening to more answers, the interpreter's understanding of the text shifts. This give and take process, this dialogical interplay of the interpreter's prejudices and the text, produces a "fusion of horizons" (Gadamer, 1989d, 388) or "consensus over meaning" (Warnke, 1987, 107) between the interpreter and the text. Understanding, as Gadamer puts it, "is, primarily, agreement" (Gadamer, 1989d, 180). Hence, the interpreter does not discover an objective meaning in the text by applying some method or mechanical process, as modernists assert. Rather, through the conversation of the hermeneutic process, the truth or meaning of the text emerges or "comes into being" (Gadamer, 1989d, 462).

Habermas has deemed himself a defender of modernism vis-à-vis postmodernism. Yet, according to my categorizations, Habermas cannot be a modernist because he unequivocally rejects subject-object metaphysics. In his words, "no plausible alternatives exist" to "postmetaphysical thinking" (Habermas, 1996, 443). To be sure, Habermas is no antimodernist, but he does fit nicely into metamodernism. He asserts, for example, that the telos of human speech is to understand. Moreover, "the hermeneutic insight," Habermas writes, "is certainly correct, viz., the insight that understanding - no matter how controlled it may be - cannot simply leap over the interpreter's relationships to tradition" (Habermas, 1977, 357). Indeed, Habermas sometimes sounds remarkably like Gadamer, as when he declares that "[h]ermeneutical understanding cannot approach a subject-matter free of any prejudice; it is, rather, unavoidably pre-possessed by the context within which the understanding subject has initially acquired his interpretative schemes" (Habermas, 1980, 183). Most important, to Habermas, reason, truth, and understanding are sowed in consensus. For instance, from Habermas's metamodernist (or postmetaphysical) vantage, truth is an intersubjective phenomenon: it arises from a consensus among a group of speakers in an "ideal speech situation," according to the earlier Habermas, or in an "ideal community," according to the later Habermas (Habermas, 1996, 322) (the Habermasian transformation will be elaborated in Part II of this essay). 
Many modernist critics of Derrida castigate him as being, in effect, the archetypical antimodernist. They accuse him of relativism, nihilism, incomprehensibility, and generally muddled thinking. This reading of Derrida is mistaken; he is best categorized as a metamodernist rather than as an antimodernist. Indeed, Gadamer himself has declared: "Obviously the principle of deconstruction involves something quite similar to what I am doing ... Derrida, too, is endeavoring to supersede any metaphysical realm of meaning which governs words and their meanings" (Gadamer, 1989a, 112). Despite the claims of his critics, then, Derrida does not deny the possibility of textual meaning. To the contrary, Derrida emphasizes that any text or event has many potential meanings; no single meaning remains fixed or stable in all contexts. A text is, in Derridean terms, iterable: it can be repeated (or read) in different contexts, so its meaning can change (Derrida, 1997, 27-28). Gadamer argues that meaning arises in part because of communal traditions or effective history. Likewise, Derrida maintains that meaning arises in part because of the "real-history-of-the-world" or the "context" for interpretation, where context refers not only to surrounding text but far more broadly to social reality (Derrida, 1988, 136-37). Our conceptual categories arise from our "heritage" so that we are, to a great extent, limited to "givens belonging to the discourse of our time" (Derrida, 1978, 285; Derrida, 1988, 8; Derrida, 1976, 70)

To be sure, Derrida is not concerned with deciding among the competing interpretations of a text. Rather, he is interested "in relations of force, in differences of force, in everything that allows, precisely, determinations [of meaning] in given situations to be stabilized." Regardless, Derrida explicitly repudiates relativism, indeterminism, and "complete freeplay or undecidability." He maintains "that there are and that there should be truth, reference, and stable contexts of interpretation," though they are "always provisional and finite." Most important, in the "pragmatically determined" practice of textual interpretation, Derrida has "never accepted saying, or encouraging others to say, just anything at all” (Derrida, 1988, 115, 137, 145, 148, 150).

\section{Triangulating Gadamer, Habermas, and Derrida}


A central issue for metamodernists is critique. How is interpretive and social critique possible within the metamodernist paradigm? This problem of critique is, in part, inherited from modernism. Modernists largely assumed that critique was possible, but they struggled, literally for centuries, to identify a firm foundation that apparently could undergird their critical forays. Metamodernists, unlike modernists, no longer quest after a firm foundation, but they nonetheless still want to take critical stances. Hence, metamodernism problematizes critique: if we are always situated in a communal or cultural context, then how can we criticize either a particular interpretation of a text or, more broadly, a societal arrangement or organization? Significantly, the problem of critique does not arise in a similar manner for antimodernists, who countenance radical relativism. But for metamodernists, such an extreme and complete repudiation of all modernist-like standards is unacceptable.

This metamodernist problem of critique leads us into the political conundrum of philosophical hermeneutics, communication theory, and deconstruction. Many commentators criticize Habermas's communication theory as "politically retrograde (since it clings to a form of enlightenment thinking whose covert aim is to repress or to marginalise everything that falls outside its privileged domain)" (Norris, 1992, 51). Indeed, this political characterization of communication theory resonates with Habermas's own assertion that he defends modernism from postmodern attacks. Yet, paradoxically, Habermas's position is in part engendered exactly by his desire to avoid the conservatism that he perceives in Gadamer's and Derrida's philosophies.

From Habermas's standpoint, Derridean deconstruction accomplishes nothing worthwhile. "The labor of deconstruction lets the refuse heap of interpretations ... mount ever higher" (Habermas, 1987a, 183). Habermas, in other words, criticizes Derrida for doing little more than offering one textual interpretation after another without explaining how to adjudicate among the competing interpretations. Deconstruction has no critical bite but rather leads to a "totalizing self-critique of reason [that] gets caught in a performative contradiction" (Habermas, 1987a, 185). Deconstruction leaves us politically paralyzed because any assertion can 
supposedly be deconstructed. Derrida ultimately is a "neo-conservative" who leads us into an inescapable relativism (Behler, 1991, 151).

Habermas's criticism of Gadamer is, in part, analogous. Philosophical hermeneutics, according to Habermas, fails to provide an adequate criterion for evaluating competing interpretations of a text. The only basis for evaluating different interpretations is the authority of tradition, and thus hermeneutics becomes an exceedingly conservative "idealism of linguisticality" (Habermas, 1977, 361). Some other commentators similarly assess Gadamer; John Caputo, for instance, calls Gadamer's philosophy “a reactionary gesture” and a "foundationalism in disguise" (Caputo, 1987, 5; Caputo, 1989, 259).

Although Habermas and Gadamer concur that the root of understanding is agreement or consensus, Habermas maintains that Gadamer fails to recognize that consensus sometimes arises not because of the truth of an assertion but because of systematic distortions of the hermeneutic process. "[E]very consensus, as the outcome of an understanding of meaning, is, in principle, suspect of having been enforced through pseudo-communication," because of "compulsion and distortion" (Habermas, 1980, 205). Here, the political conundrum animating the relations among Habermas, Gadamer, and Derrida becomes paramount. Recall that Habermas placed himself to the left of a politically conservative relativism that he perceived in both Derrida and Gadamer. Oddly, however, Derrida articulates a critique of Gadamer that resonates strongly with Habermas's position vis-à-vis Gadamer. In fact, Habermas's criticism of Gadamer, at points, seems to echo Derridean language, as when Habermas writes that "the context of tradition as a locus of possible truth and factual agreement is, at the same time, the locus of factual untruth and continued force" (Habermas, 1980, 205).

The thrust of both Habermas's and Derrida's criticisms of Gadamer is that the latter is, perhaps, too sanguine. Gadamer too readily accepts the authority of tradition and too freely anticipates an intelligible and unified textual meaning. Derrida's description of the hermeneutic process and his method of deconstruction illuminate this critique of Gadamer. According to Derrida, meaning is never grounded on a stable signified, rather there "is always already" a play 
of signifiers (Derrida, 1976, 73). "From the moment that there is meaning there are nothing but signs. We think only in signs. Which amounts to ruining the notion of the sign... One could call play the absence of the transcendental signified as limitlessness of play, that is to say as the destruction of ... the metaphysics of presence" (Derrida, 1976, 50). Thus, the interpretation of a text or any other hermeneutic activity involves the continual play or "coming into being" of signs or signifiers (Derrida, 1976, 48). "[E]very concept is inscribed in a chain or in a system within which it refers to the other, to other concepts, by means of the systematic play of differences" (Derrida, 1982, 11). This play of signifiers provides the key to understanding Derrida's central concept (or non-concept, as Derrida sometimes says) of différance, which accentuates that an asserted textual meaning always denies, suppresses, or ignores some alternative meaning or meanings, some marginalized Other. No signifier or "element can function as a sign without referring to another element which itself is not simply present." Each signifier or element is therefore "constituted on the basis of the trace within it of the other elements of the chain or system." There are only differences and traces of differences. "Différance is the systematic play of differences, of the traces of differences, of the spacing by means of which elements are related to each other" (Derrida, 1981, 26-27).

Thus, Derrida and Gadamer both focus on the processes or conditions of understanding. The crucial distinction between Derrida and Gadamer, however, lies in their respective emphases as they explore the hermeneutic situation. Whereas Gadamer focuses on the constructive and enabling power of our interpretive being-in-the-world, Derrida focuses on the destructive and disabling element. Gadamer's philosophical hermeneutics emphasizes how our traditions and concomitant prejudices enable us to open to the meaning of a text, but Derridean deconstruction stresses how traditions and prejudices always constrain communication and understanding. Every hermeneutic situation entails not only the production of meaning but also the destruction or denial of meaning. "[E]ven as our prejudices enable us to understand, they simultaneously prevent us from seeing or understanding alternative meanings in a text-our prejudices blind us to the face of the Other" (Feldman, 2000, 60). 
Moreover, Derrida underscores that the concept of tradition should not be reified. Tradition does not exist in some ideal and static form; it must constantly be constituted and reconstituted. While this constant reconstitution is both constructive and destructive, Derrida focuses on the destructive aspect. As we participate in and reconstitute tradition, we necessarily exclude from it certain prejudices, interests, and participants. No tradition is all-encompassing or all-inclusive. Thus, Derrida warns us that the authority of tradition necessarily emerges from "irreducible violence" (Derrida, 1988, 137). Tradition opens us to understanding because in part it provides an authoritative background context for the hermeneutic act. Tradition thus operates most effectively when it remains in the background, forgotten from conscious memory. But Derrida wants to remind us about tradition, to bring the background to the foreground, and to underscore how tradition often establishes its authority through brutality and duplicity. It is the "conflicts, tensions, differences of force, [and] hegemonies" that, according to Derrida, produce apparently stable textual meanings (Derrida, 1988, 145).

Consequently, while Derrida readily admits that any text has many potential meanings, he cares little about deciding among them — exactly because he stresses the disempowering and destructive quality of the hermeneutic situation. Disempowerment, quite simply, is not about making decisions; rather, it is about lacking the power to decide. Unlike Gadamer, Derrida is not especially interested in the practical component of the hermeneutic act since he does not seek to pursue or reconstruct a unified meaning for the text. To pursue a unified meaning - to assume its presence - would be, in Derridean language, logocentric. Instead, Derrida seeks to find and highlight the trace of the Other that always hides in the margins of our understanding. Derrida seeks to uncover the violence that necessarily exists when we understand a text- - the violence that is inevitably obscured in the practical quest for a usable unified meaning. To Derrida, violence manifests itself in the hermeneutic definition, exclusion, denial, and oppression of the Other - a concealed outsider - and this violence stands as an unavoidable condition (or limit) of human understanding. Within the hermeneutic process of understanding, we always and already define some Other; we necessarily deny the potential meanings arising from some other 
perspective and exclude those potential meanings from our communal traditions. Without the Other, without the trace of denied potential meaning, "no meaning would appear" at all (Derrida, $1976,62)$.

Significantly, then, deconstruction is not just a method of critical reading, but rather a means of social and political critique. Derrida has gone so far as to claim that "deconstruction is justice" (Derrida, 1990, 945). In other words, Derridean deconstruction is, from this perspective, politically progressive: it uncovers the hidden, the oppressed, the violated, the denied - the Other. ${ }^{3}$ Deconstruction responds to the call from the Other. Derrida wants to reveal the Otherness suppressed by our understanding of the text. He proclaims that deconstruction insists "on the heterogeneity, the difference, the disassociation, which is absolutely necessary for the relation to the other. The privilege granted to unity, to totality, to organic ensembles, to community as a homogenized whole — this is a danger . . for ethics, for politics" (Derrida, 1997, 13).

Habermas further develops his criticism of Gadamer's optimistic view of the hermeneutic situation in a related fashion. Like Derrida, Habermas seeks to uncover how the background consensus embodied in tradition can arise because of domination or other distortive forces. Habermas, though, is more programmatic than Derrida. Derrida (and other deconstructionists) use assorted critical approaches in their deconstructive readings of different texts. There is no one deconstructive method; rather there are deconstructive methods. Habermas, meanwhile, seeks to identify precisely and methodically the forces that can systematically distort the hermeneutic process. To this purpose, Habermas distinguishes between, on the one hand, the communicative interaction and symbolic reproduction of our "lifeworld" and, on the other hand, the strategic interaction and material reproduction of our economic and administrative systems (Habermas, 1984, 340-43; Habermas, 1987b, 150-52). Within the economic and administrative systems, strategically rational actions are sometimes appropriate. For example, we might act strategically in the economic marketplace to try to maximize our profits without regard for the effects on other actors. Yet, while perhaps appropriate to the economic and administrative 
systems, such strategic rationality inevitably interferes with communicative action or discourse. Communicative interaction in the lifeworld should be directed toward mutual understanding and governed by the force of the best argument, but when strategic rationality colonizes our lifeworld, then communication is skewed or distorted. The best argument no longer necessarily wins.

To correct for this defect in communication, Habermas proposes a critical method. To explain this critical method, though, it is helpful to distinguish the earlier from the later Habermas, given that he has modified his initial method in reaction to criticisms. To be sure, Habermas has not repudiated his early approach. In fact, sometimes Habermas suggests that critics have misunderstood his method, so that he has needed to clarify but has not truly changed it (Habermas, 1996, 322-23; Habermas, 1990, 88). Regardless of whether this is true, the later Habermas shares significant points of commonality with the earlier Habermas.

The earlier Habermas initially posited a critical method that could supposedly produce "communication free from domination," that could purify discourse by removing the distortions which arise from strategic and material forces (Habermas, 1971, 53). The crux of Habermas's critical method was his conception of the ideal speech situation: an intersubjective encounter cleansed of domination, coercion, and other distortions (Habermas, 1980, 206; Habermas, 1976, 105-10). By analyzing the "transcendental character of ordinary language," Habermas identified three "universal validity claims" as definitive of the ideal speech situation (Habermas, 1979, 2; Habermas, 1976, 110). Habermas, that is, maintained that any speaker engaged in communicative action presupposed the validity claims - truth, rightness, and truthfulness - as "universal structures of speech — what is common to all utterances independently of their particular contexts" (Habermas, 1979, 27, 65-66). A consensus that emerges within the ideal speech situation would supposedly reflect the force of the best argument only and thus would allow us to identify truth and normative legitimacy. The ideal speech situation, as such, "makes possible unforced universal agreement" (Habermas, 1980, 206). 
Significantly, and in contrast to the Gadamerian standpoint, the earlier Habermas argued that unless we posit the ideal speech situation as a critical standpoint, we would have no means for distinguishing between a legitimate communicative consensus that manifests truth and an illegitimate consensus that arose from distorted communicative processes. We need some "meta-hermeneutic" approach so that we can critique communication and consensus; we must have, in other words, "a reference system that goes beyond the framework of tradition as such; only then can tradition also be criticized" (Habermas, 1977, 358; Habermas, 1980, 205). Otherwise, we are likely to succumb to ideological forces, without being aware that we are doing so.

Gadamer responds to such criticisms in two basic ways. In one type of response, which Gadamer articulates especially in his exchange with Habermas, Gadamer seems highly defensive and ultimately conservative. He dwells on the importance of tradition within the hermeneutic process, and indeed, at points, he seems to imbue tradition with an unquestioned normative authority. He discusses "an acknowledgment of authority" and explains that "[a]uthority can rule only because it is freely recognized and accepted." One can accept authority, Gadamer continues, because "one concedes superiority in knowledge and insight to the authority" (Gadamer, 1976, 33-34).

Gadamer's other type of response follows more closely, perhaps, from his broad conception of philosophical hermeneutics. It is not only less conservative but appears, in some ways, to move Gadamer to the left of Habermas and Derrida. The crux of the Gadamerian move is to accentuate the critical dimensions that are inherent to the hermeneutic process itself, as Gadamer describes it. In fact, the presence of these inherent critical dimensions has led an increasing number of political philosophers and jurisprudents to explore the relations among philosophical hermeneutics, justice, and critical theory (Warnke, 1992, 128-34; Mootz, 2000, 720-27). These theorists draw on numerous passages where Gadamer elaborates interpretation as a recognition of the Other and a challenge to the status quo. Whenever we seek to understand a text, we are confronted with something foreign, with an otherness. "Every 
interpretation," Gadamer tells us, "includes the possibility of a relationship with others" (Gadamer, 1989d, 397). But "to experience the other's claim to truth," Gadamer explains, our own prejudices and traditions must be "brought into play by being put at risk" (Gadamer, 1989d, 299). We should not attempt to defeat the Other, but rather recognize "that I myself must accept some things that are against me" (Gadamer, 1989d, 361). Thus, from a personal standpoint, the interpreter risks her own prejudices, and from a social standpoint, the interpreter questions the underlying communal traditions. The interpreter's own prejudices and traditions are, in other words, "at stake" (Gadamer, 1989d, 568). The (interpretive) critique of political and social conventions, including communal traditions, is always possible (Gadamer, 1989d, 547); we just need to recognize the potential and to make the effort. We do not need to struggle through Derridean deconstructive shenanigans or commit to pseudo-scientific Habermasian forays. To criticize the political status quo, to question current economic and other societal arrangements, we need only to use our interpretive tools as we always use them.

In specific answer to Derrida, then, Gadamer makes a simple point. He emphasizes the practical dimension of interpretation. When we approach a text, we typically do so for the practical purpose of understanding its meaning. For that reason, we anticipate the completeness of the text and presume that it can communicate a "unity of meaning" (Gadamer, 1989d, 29394). Otherwise, the hermeneutic act would become merely a hypothetical rather than a purposive activity. In direct retort to Derrida, Gadamer declares: "Whoever opens his mouth wants to be understood; otherwise, one would neither speak nor write" (Gadamer, 1989b, 55). Yet, given Gadamer's conceptualization of interpretation, he unsurprisingly acknowledges an affinity between philosophical hermeneutics and deconstruction. After all, as Gadamer reiterates in his dialogue with Derrida, textual understanding requires us to risk our own prejudices, to recognize "a potentiality for being other" (Gadamer, 1989c, 26).

Turning specifically to Habermas, Gadamer again finds solace within the parameters of the hermeneutic process. Gadamer rejects Habermas's critical method by insisting that the hermeneutic situation is unavoidable (or universal): we can never escape our interpretive being- 
in-the-world (Gadamer, 1980, 128, 134). For that reason, according to Gadamer, there never can be a critical reference system that stands outside of tradition (Gadamer, 1976, 31). Critical activity must itself be an interpretive act rather than a meta-hermeneutic process or method. The problem of critique is, in short, specious. Critical activity not only is possible; it proceeds the same as any other interpretive activity. If we wish to question the justice of a particular political arrangement, we open to the meaning of justice (and injustice) only because of our hermeneutic being-in-the-world. From a Gadamerian vantage, the earlier Habermas's claims regarding the ideal speech situation - that it arises from universal validity claims and that it elicits universal truths - are reactionary moves. Habermas appears to yearn conservatively and nostalgically to save the Enlightenment legacy of transcendence.

On this last point, Derrida stands with Gadamer to the left of Habermas, as Derrida denounces Habermas for protecting “[o]ld and familiar oppositions ... at all costs” (Derrida, 1988, 156 n.9). Derrida acknowledges that we can at least posit regulative ideals to direct interpretation, and thus, it follows, we might posit something akin to Habermas's ideal speech situation. But for Habermas and Derrida, the possibility of positing such an idealization has very different consequences. For the earlier Habermas, the apolitical and neutral validity claims of the ideal speech situation - the posited transcendence of real forces of domination and manipulation - enable us to speak of universals. Why? The supposed point of the ideal speech situation is that it can be repeated infinitely, in all contexts, because it is actually independent of context. But from the Derridean vantage, any such idealization "is unattainable, [because] the determination, or even the redetermination, the simple recalling of a context is never a gesture that is neutral, innocent, transparent, distinterested." Interpretation and understanding are never possible outside of a context — outside of our situatedness — and no context is ever politically or culturally neutral. Moreover, even the mere positing of any idealization is necessarily contextual and therefore political and cultural. We might be able to posit some regulative ideal, but even so, there always is some marginalized or oppressed Other. Unsurprisingly, then, many commentators have argued that Habermas's communication theory does not demonstrate the 
existence of universals but rather reflects his own horizon within the traditions of Western philosophy and social theory. Derrida may be hyperbolic but nonetheless plausible when he suggests, at one point, that Habermas writes in "the most authoritarian manner" (Derrida, 1988, 131, 158 n.9).

To be fair to Habermas, though, one must attend to his later developments. Because of the Kantian nature of Habermas's early arguments - his reference to the transcendental, his invocation of universals, his demand for a meta-hermeneutic - critics accused him of following the "legacy of idealist philosophy" by relying on "utopian" assumptions and "a priori" ideals (Bubner, 1982, 46, 48). Partly in reaction to such criticisms, Habermas repudiated transcendentalism and instead insisted that his argument should be understood as a "rational reconstruction" (Habermas, 1982, 234). The later Habermas, nevertheless, still seeks to specify the same "criticizable validity claims" (Habermas, 1984, 15), but instead of identifying them through a form of transcendental argument, he rationally reconstructs "the know-how of subjects who are capable of speech and action" (Habermas, 1990, 31). The validity claims are posited, in other words, as "counterfactual presuppositions assumed by participants in argumentation," as regulative idealizations, rather than as a priori ideals (Habermas, 1996, 323). Habermas insists, then, that he has avoided any transcendental references to a "noumenal realm," and instead has discovered "the unavoidable pragmatic presuppositions of speech acts ... in the heart of ordinary, everyday communicative practice" (Habermas, 1996, 19). Regardless of this supposed change in the form of his argument, Habermas continues to maintain that "the fundamental intuition of every competent speaker - that his claims to truth, normative rightness, and truthfulness should be acceptable to all, under suitable conditions - ... [focuses] on the general and necessary conditions for the validity of symbolic expressions and achievements" (Habermas, 1990, 31). Thus, unsurprisingly, Habermas still occasionally refers to the ideal speech situation, though he now equates it with an "ideal community" or "ideal communication community" (Habermas, 1996, 322). "In this sense, communicative action refers to a process of argumentation in which those taking part justify their validity claims before an ideally expanded audience," Habermas 
explains. "Participants in argumentation proceed on the idealizing assumption of a communication community without limits in social space and historical time" (Habermas, 1996, 322).

What precisely, then, is the difference between the earlier and the later Habermas? The earlier Habermas focused on the abstract specification of universal norms (the validity claims) that could supposedly ground the substantive critique of communication. The later Habermas instead focuses on the practical attempts of individuals to communicate or reach a consensus and, more specifically, the procedures that they must presuppose in order to do so. As such, the later Habermas acknowledges that communication is always situated within a context: communicative actors cannot "take up an extramundane position in relation to their lifeworld" (Habermas, 1987b, 125). Communicative actions, Habermas elaborates, “depend on content brought to them from outside. It would be utterly pointless to engage in a practical discourse without a horizon provided by the lifeworld of a specific social group and without real conflicts in a concrete situation in which the actors consider it incumbent upon them to reach a consensual means of regulating some controversial social matter" (Habermas, 1990, 103). Habermas consequently seeks to identify the procedures that must be presupposed by individuals, moving within such a practical context, who seek to reach a legitimate consensus, and those procedures are, of course, the validity claims. The validity claims are, in a sense, "context-transcending" regulative idealizations because they must be presupposed by any and all individuals who wish to make a good faith effort at reaching a consensus (Habermas, 1996, 323). Any rational individual engaged in communicative action must, for instance, be committed to ascertaining or discursively redeeming the truth: to defending and modifying overt and underlying assertions of fact in accordance with relevant evidence brought to light through the questions and assertions of other good-faith individuals.

The later Habermas's communication theory is "formal" because the validity claims, as procedural devices, supposedly are bereft of substantive content themselves (Habermas, 1984, 328; Habermas, 1990, 103). The validity claims, that is, do not constitute substantive 
criteria or standards for evaluating the results of communicative deliberations, yet the validity claims provide the procedures that, if followed, enable us to arrive at substantive norms (Habermas, 1996, 322-23). More precisely, the validity claims of communicative action do not produce "justified norms" per se, but rather provide "a procedure for testing the validity of norms that are being proposed and hypothetically considered for adoption" (Habermas, 1990, 103). When individuals deliberate about substantive norms, Habermas tells us, discourse that proceeds in accordance with the validity claims for an endless time and before an endlessly expanding audience will produce rational and legitimate agreement.

Despite Habermas's efforts to distinguish his later from his earlier arguments, he ultimately seems to leave himself open to similar criticisms, particularly from Derrida on the left. Whereas Gadamer and Derrida would seem to share similarly skeptical views of the earlier Habermas's claims regarding the ideal speech situation and the existence of universals, Derridean deconstruction seems to move to the left of Gadamer as well as the earlier and later Habermas in a different though related respect. Recall that Habermas positioned himself to the left of Gadamer when Habermas argued that philosophical hermeneutics was a type of linguistic idealism. Habermas agreed with Gadamer that understanding arose from consensus, but according to Habermas, Gadamer failed to account for the likely possibility that such consensus (embodied in tradition and interpretation) would be infected and therefore skewed by material and strategic forces. The earlier Habermas therefore proposed the ideal speech situation as a mechanism for purifying the lifeworld of these distortive forces.

As already discussed, Derrida largely agrees with Habermas that Gadamer is too sanguine about the possibility of consensus. Yet, Derrida then moves to the earlier Habermas's left by questioning the possibility of purifying the hermeneutic process. That is, the earlier Habermas insisted that communication within the lifeworld could be purified of the distortions that arise from material and strategic forces. This viewpoint led Habermas to propose the ideal speech situation as a communicative context cleansed of all distortive forces, and as such, the ideal speech situation supposedly could engender universal agreement. Derridean 
deconstruction, however, suggests that communication and the hermeneutic process can never be so purified. The hermeneutic process itself always and inescapably entails some degree of suppression. There always is some Other. The marginalization of the Other cannot be cleansed from communication because, according to Derrida, it is integral to communication in the first place. Thus, any ostensible consensus, even one arising from a posited ideal speech situation, must necessarily arise in part from domination or distortion. From a Derridean perspective, once the earlier Habermas claimed to cleanse the hermeneutic process of the distortive forces inherent to economic and administrative systems, then Habermas's conception of symbolic reproduction in the lifeworld looked remarkably similar to Gadamer's conception of interpretation. Like Gadamer, in other words, the earlier Habermas seemed far too sanguine about the possibility of attaining unforced and legitimate consensus.

Moreover, even the later Habermas remains vulnerable to this Derridean critique. ${ }^{4}$ While Habermas no longer seems as intent upon purifying communicative action in a transcendental manner, he nonetheless continues to use rhetoric that suggests an analogous type of communicative catharsis. And he does so over and over again. For instance, Habermas stresses an "original mode of language," free of coercion, manipulation, and distortion: "the use of language with an orientation to reaching understanding is the original mode of language use, upon which indirect understanding, giving something to understand or letting something be understood, and the instrumental use of language in general, are parasitic" (Habermas, 1984, 288). Likewise, he talks of immunity from coercive forces: "In argumentative speech we see the structures of a speech situation immune to repression and inequality" (Habermas, 1990, 88). Habermas explains that communicative action or practical discourse "insures that all concerned in principle take part, freely and equally, in a cooperative search for truth, where nothing coerces anyone except the force of the better argument" (Habermas, 1990, 198). In fact, even though the later Habermas acknowledges the inescapability of context, he still insists that "[t]he counterfactual presuppositions assumed by participants in argumentation ... open up a 
perspective allowing them to go beyond local practices of justification and to transcend the provinciality of their spatiotemporal contexts" (Habermas, 1996, 323).

From the Derridean standpoint, Habermas mistakenly fails to recognize the deepness of distortive and coercive power in communication. Communication is, we might say, distortion and coercion all the way down —or at least that is what deconstruction asserts. Distortive and coercive power always and already are part of the communicative process at two points. First, since communication must unfold against a background context—which the later Habermas sometimes admits - then the limits of that context will necessarily constrain communication. Second, and perhaps more important, Habermas claims to identify presuppositions of communicative action, which he specifies as the three validity claims. One of Derrida's most central points, however, is that distortion and coercion — the marginalization of the Other-is also a presupposition of communication. Thus, even if Habermas correctly identifies the validity claims as communicative presuppositions, he fails to recognize an additional presupposition, the marginalization of the Other, which, not incidentally, problematizes Habermas's validity claims. So, for example, when the later Habermas posits "a speech situation immune to repression and inequality" (Habermas, 1990, 88), Derrida would reply that repression and inequality are inherent to speech. Without repression and inequality, we do not speak.

\section{The Problem of Critique: Concluding Remarks}

Gadamer, Derrida, and Habermas are metamodernists. They reject the subject-object metaphysics of modernism and instead maintain that our being-in-the-world is interpretive and contextual. The disagreements among Gadamer, Derrida, and Habermas arise largely from their efforts to come to grips with the implications of the metamodernist paradigm as they discuss the orientation of power, especially through language, within the hermeneutic process. Most important, they disagree about interpretive and social critique: how is critique possible within the metamodernist paradigm?

Their respective approaches to critique lead to the paradoxical political intransitivity of philosophical hermeneutics, communication theory, and deconstruction. Rather than being fixed 
in relation to each other, the three philosophies seem to move around the points of a triangle situated within the paradigm of metamodernism. This political conundrum arises in part because of the incipient nature of metamodernism. The apparently shifting political relations among philosophical hermeneutics, communication theory, and deconstruction reveal the problematic ambiguities in our understanding of understanding (or in our understanding of the hermeneutic process).

These paradoxical political relations, moreover, underscore the current central issues within the metamodernist paradigm. The traditional (modernist) political labels of liberalism (to the left) and conservatism (to the right) do not suitably identify the critical positions in the metamodernist scheme. After all, political liberalism and conservatism ordinarily reflect either, on the one hand, a strong (liberal) commitment to the autonomous and independent self-except in the economic marketplace - or, on the other hand, a strong (conservative) commitment to preserving traditional communal values. Liberalism and conservatism, in other words, resonate with the subject-object metaphysics that metamodernists reject. Metamodernists reconceptualize the self or subject as socially constructed, partly through participation in communal traditions. To be sure, metamodernists occasionally accuse each other of conservatism. Even so, their primary concern is not with remaining true to a traditional political agenda of liberalism or conservatism. Rather, they seek to explain interpretive and social critique while simultaneously operating within the metamodernist paradigm. The problem of critique, it would seem, requires a self-reflexive understanding of the factors that influence the hermeneutic process. Thus, to understand critique, we need to understand the contours of the metamodernist paradigm.

From a metamodernist perspective, our hermeneutic situation - our situatedness in communal traditions - both enables and constrains understanding and communication. Gadamer most clearly articulates this description of our interpretive being-in-the-world. When the issue specifically becomes the problem of interpretive and social critique, however, Gadamer adds little-because, he maintains, little needs to be added. He argues that critique emerges through the ordinary hermeneutic processes, as with any other practical interpretive activity. 
To Habermas, Gadamer is overly optimistic about the legitimacy of our hermeneutic context. Habermas maintains that we can, in effect, separate different realms of activity. The lifeworld is but one realm - the realm of symbolic reproduction or, in other words, the hermeneutic realm of communication, interpretation, and understanding. By identifying separate realms of activity, Habermas claims to identify specific sources that skew or distort the hermeneutic realm and that then can be eliminated or at least diminished. In particular, communal traditions and hermeneutic prejudices might be illegitimately produced when the economic and administrative realms colonize the lifeworld. In those instances, strategic and material forces, from the economic and administrative systems, distort the hermeneutic processes of the lifeworld.

If Habermas were correct about the possibility of separating different realms of activity, then his approach would have certain interrelated ramifications. First, hermeneutics could not be unavoidable or universal in the sense that Gadamer argues. If it were unavoidable or universal, then Habermas would not be able to specify other realms of activity that supposedly colonize the hermeneutic realm or lifeworld. Second, the earlier Habermas would have been correct to posit a meta-hermeneutic method — such as the application of the ideal speech situation — that would facilitate the filtering of impurities or distortive forces from the hermeneutic realm. Third, Habermas could still maintain, along with Gadamer, that all understanding is hermeneutic, rather than methodical or mechanical (as modernists argue). That is, once the hermeneutic realm is either cleansed of impurities from the economic and administrative realms (the earlier Habermas) or pronounced immune from coercion (the later Habermas), then Habermas would largely agree with Gadamer's description of understanding and communication. Unsurprisingly, then, Habermas writes that "hermeneutical understanding always has to proceed in an ad hoc way and cannot be developed into a scientific method" (Habermas, 1980, 189).

Gadamer insists, nevertheless, that if critique is to be communicated and understood (and how could we aim for anything else?), then it must be hermeneutic. Derridean deconstruction adds yet a different perspective. To Derrida, both Gadamer and Habermas too readily accept the 
outcomes of the hermeneutic process. The hermeneutic realm, according to Derrida, can never be immunized from distortive and coercive forces because such forces are part-and-parcel of communication and understanding. For Derrida, social and interpretive critique is, in a sense, immanent: it comes from within the hermeneutic process itself. There always and already is a critical voice - the voice of the Other-obscured or marginalized within communication and understanding. We never can hear all voices equally and simultaneously in any meaningful fashion. Deconstructive critique thus partly entails disclosing or uncovering that hidden or oppressed voice.

In sum, the disagreements among Gadamer, Habermas, and Derrida disclose some of the issues that presently seem most pressing within the metamodernist paradigm. Most broadly, how is critique possible? More specifically, must or can critique arise from within the hermeneutic process itself? Must or can critique somehow enter from outside the hermeneutic process? Is there anything meaningful outside the hermeneutic process? Does critique require some special method or methods? While Gadamer, Habermas, and Derrida all provide valuable insights, none of them has supplied the final answers to these questions. 


\section{Notes}

${ }^{1}$ In a somewhat similar fashion, Steven Best and Douglas Kellner distinguish between "extreme" and "reconstructive" postmodernists (Best and Kellner, 1997, 258).

${ }^{2}$ I am focusing here on Gadamer's conception of the human sciences. His more recent discussions of the natural sciences suggest that he views them as significantly different from the human sciences. Indeed, Gadamer might disagree with Kuhn's notion of natural science and instead adhere to a more traditional view (Gadamer, 1998, 29-31; Gadamer, 1996, 2). This possibility, however, is irrelevant to my categorization of both Kuhn (with regard to the natural sciences) and Gadamer (with regard to the human sciences) as metamodernists.

${ }^{3}$ For a recent exchange regarding Derrida's deconstructive notion of justice and its relation to violence, see (McCormick, 2001a; Corson, 2001; McCormick, 2001b).

${ }^{4}$ Habermas has recently applied his communication theory in the context of democratic government (Habermas, 1996), and has focused particularly on the problematic relation between constitutional rights and democracy (Habermas, 1998, 203-36; Habermas, 2001). 
Triangulating- 30 - 


\section{References}

Behler, E. 1991. Confrontations: Derrida, Heidegger, Nietzsche. Trans. Steven Taubeneck. Stanford, Calif.: Stanford University Press.

Bernstein, R. J. 1991. The new constellation: The ethical-political horizons of modernity/ postmodernity. Cambridge, Eng.: Polity Press.

Best, S., and D. Kellner. 1997. The postmodern turn. New York: Guilford Press.

Bloom, H. 1979. The Breaking of Form. In Deconstruction and criticism, 1-38. New York: Seabury Press.

Bork, R. H. 1990. The tempting of America. New York London: Free Press Collier Macmillan.

Bubner, R. 1982. Habermas's Concept of Critical Theory. In Habermas: Critical Debates, eds J. B. \&. H. Thompson, David, 42-56. Cambridge, Mass.: MIT Press.

Caputo, J. D. 1987. Radical hermeneutics. Bloomington: Indiana University Press.

-----. 1989. Gadamer's closet essentialism: A Derridean critique. In Dialogue and deconstruction: The Gadamer-Derrida encounter, ed. R. E. Palmer and D. P. Michelfelder, 258-64. Albany: State University of New York Press.

Corson, B. 2001. Transcending violence in Derrida: A Reply to John McCormick. Political Theory 29(6):866-75.

Derrida, J. 1973. Speech and phenomena. Trans. D. B. Allison. Evanston: Northwestern University Press.

-----. 1976. Of grammatology. Trans. G. C. Spivak. Baltimore: Johns Hopkins University Press.

-----. 1978. Writing and difference. Trans. A. Bass. Chicago: University of Chicago Press.

-----. 1981. Positions. Trans. A. Bass. Chicago: University of Chicago Press.

-----. 1982. Margins of philosophy. Trans. A. Bass. Chicago: University of Chicago Press.

-----. 1988. Limited Inc. Trans. S. Weber. Evanston, IL: Northwestern University Press. 
------. 1990. Force of law: The 'mystical foundation of authority'. Cardozo Law Review 11:919.

------. 1997. Deconstruction in a nutshell: A conversation with Jacques Derrida. Ed. J. D.

Caputo. New York: Fordham University Press.

Dworkin, R. 1996. Objectivity and truth: You'd better believe it. Philosophy and Public Affairs 25(2):87.

Feldman, S. M. 2000. Made for each other: The interdependence of deconstruction and philosophical hermeneutics. Philosophy and Social Criticism 26(1):51-70.

Gadamer, H.-G. 1976. Philosophical hermeneutics. Trans. D. E. Linge. Berkeley: University of California Press.

-----. 1980. The Universality of the Hermeneutical Problem. In Contemporary hermeneutics: Hermeneutics as method, philosophy, and critique, ed. J. Bleicher, 128-40. London Boston: Routledge \& Kegan Paul.

-----. 1989a. Destruktion and deconstruction. In Dialogue and deconstruction: The GadamerDerrida encounter, ed. R. E. Palmer and D. P. Michelfelder, 102-13. Albany: State University of New York Press.

-----. 1989b. Reply to Jacques Derrida. In Dialogue and deconstruction: The Gadamer-Derrida encounter, ed. R. E. Palmer and D. P. Michelfelder, 55-57. Albany: State University of New York Press.

-----. 1989c. Text and interpretation. In Dialogue and deconstruction: The Gadamer-Derrida encounter, ed. R. E. Palmer and D. P. Michelfelder, 21-51. Albany: State University of New York Press.

------. 1989d. Truth and method. 2nd revised ed. Trans. J. Weinsheimer and D. Marshall. New York: Crossroad.

-----. 1996. The enigma of health: The art of healing in a scientific age. Stanford, Calif.: Stanford University Press.

-----. 1998. The beginning of philosophy. Trans. R. R. Coltman. New York: Continuum. Habermas, J. 1971. Knowledge and human interests. Boston: Beacon Press. 
------. 1976. Legitimation crisis. London: Heinemann. U of Toronto.

------. 1977. A review of Gadamer's Truth and Method. In Understanding and social inquiry, ed.

T. A. McCarthy and F. R. Dallmayr, 335-63. Notre Dame, Ind.: University of Notre Dame Press.

-----. 1979. Communication and the evolution of society. Boston: Beacon Press.

------ 1980. The Hermeneutic Claim to Universality. In Contemporary hermeneutics:

Hermeneutics as method, philosophy, and critique, ed. J. Bleicher, 181-211. London Boston: Routledge \& Kegan Paul.

-----. 1982. A Reply to My Critics. In Habermas: Critical Debates, eds J. B. \&. H. Thompson, David, 219-83. Cambridge, Mass.: MIT Press.

------ 1984. The theory of communicative action: Reason and the rationalization of society. Trans. T. McCarthy. Boston: Beacon Press.

-----. 1987a. The philosophical discourse of modernity. Trans. F. Lawrence. Cambridge, Mass.: M.I.T. Press.

-----. 1987b. The theory of communicative action: Lifeworld and system. Trans. T. McCarthy. Boston: Beacon Press.

------ 1990. Moral consciousness and communicative action. Studies in contemporary German social thought. Cambridge, Mass.: MIT Press.

------ 1996. Between facts and norms: Contributions to a discourse theory of law and democracy. Trans. W. Rehg. Cambridge, Mass.: MIT Press.

------. 1998. The inclusion of the other: Studies in political theory. Ed. C. Cronin and P. De Greiff. Studies in contemporary German social thought. Cambridge, Mass.: MIT Press.

------. 2001. Constitutional democracy: A paradoxical union of contradictory principles? Political Theory 29(6):766-81.

Kenny, A. 1998. A brief history of western philosophy. Oxford: Blackwell Publishers.

Kuhn, T. S. 1970. The structure of scientific revolutions. Chicago: University of Chicago Press. 
Leiter, B. 1998 Fall. Books in Review. ABA Division for Public Education Focus on Law Studies:14.

Lessnoff, M. H. 1999. Political philosophers of the twentieth century. Oxford, UK: Basil Blackwell, Inc.

Levinson, S. 1982. Law as literature. Texas Law Review 60:373-403.

Madison, G. B. 1989. Gadamer/Derrida: The hermeneutics of irony and power. In Dialogue and deconstruction: The Gadamer-Derrida encounter, ed. R. E. Palmer and D. P. Michelfelder, 192-98. Albany: State University of New York Press.

McCarthy, T. A. 1991. Ideals and illusions: On reconstruction and deconstruction in contemporary critical theory. Cambridge, Mass.: MIT Press.

McCormick, J. P. 2001a. Derrida on law; or poststructuralism gets serious. Political Theory 29(3):395-423.

------. 2001b. Justice, interpretation, and violence: A rejoinder to Corson. Political Theory 29(6):876-81.

Mootz, F. J. 2000. Foreword: Symposium on Philosophical Hermeneutics and Critical Legal Theory. Chicago-Kent Law Review 76(2):719-30.

Murphy, N. C. 1997. Anglo-American postmodernity: Philosophical perspectives on science, religion, and ethics. Boulder, Colo.: Westview Press.

Norris, C. 1992. What's wrong with postmodernism: Critical theory and the ends of philosophy. Baltimore: Johns Hopkins University Press.

Patterson, D. 1992. Postmodernism/feminism/law. Cornell Law Review 77:254-317.

Ricoeur, P. 1981. Hermeneutics and the human sciences. Trans. J. B. Thompson. Cambridge [Eng.] New York Paris: Cambridge University Press Editions de la Maison des sciences de l'homme.

Risser, J. 1997. Hermeneutics and the voice of the other. Albany: State University of New York Press. 
Rorty, R. 1982. Consequences of pragmatism essays, 1972-1980. Minneapolis: University of Minnesota Press.

Schmitt, F. F. 1995. Truth: A primer. Boulder, Colo.: Westview Press.

Searle, J. R. 1998. Mind, language and society: Philosophy in the real world. New York, NY: Basic Books.

Shiffrin, S. H. 1999. Dissent, injustice, and the meanings of America. Princeton, N.J.: Princeton University Press.

Warnke, G. 1987. Gadamer: Hermeneutics, tradition and reason. Cambridge: Polity Press.

-----. 1992. Justice and interpretation. Cambridge: Polity Press. 